\title{
TOXICITY STUDY OF PARE LEAF EXTRACTS (MOMORDICA CHARANTIA) TO CULEX PIPIENS MOSQUITO LARVAE
}

\author{
1*Rahmi Annisa, ${ }^{2}$ Muhammad Amir, ${ }^{2}$ Hadi Kuncoro \\ ${ }^{1}$ Department of Pharmacy, Faculty of Medicine and Health Sciences \\ Universitas Islam Negeri Maulana Malik Ibrahim, Malang, Indonesia \\ 2 Faculty of Pharmacy, Universitas Mulawarman, Samarinda, Indonesia \\ * Email : apt.rahmiannisa@gmail.com
}

\begin{abstract}
This study aims to determine the yield, toxicity, and toxic concentration of crude extracts of ethanol, $n$-hexane fraction extract, ethyl acetate fraction extract and n-butanol fractions extract pare leaf (Momordica charantiaL.) larvae Culex pipiens. The method used to determine the toxicity of extract larvasida test larvae Culex pipiens to obtain the $\mathrm{LC}_{99}$ values obtained using the analysis of Reed and Muench. Extraction and fractionation processis known to yield a ethanol crude extract obtained $8.86 \%$, n-hexane fraction extract of $1 \%$, ethyl acetate fraction extract $1.80 \%$ and n-butanol fractions extract of $0.80 \%$ and the toxicity obtained test results that pare leaf (Momordica charantia L.) have the potential toxicity larvae larvae of Culex pipiens as indicated by the value by Lethality Concrentation $99 \%\left(\mathrm{LC}_{99}\right)$ in the crude extract ethanol $7416.52 \mathrm{ppm}$, n-hexane fraction extract of $2564.48 \mathrm{ppm}$, ethyl acetate fraction extract $2702.09 \mathrm{ppm}$ and n-butanol fractions extract of 2665.63 ppm.
\end{abstract}

Keywords: Pare leaf (Momordica charantia L.), toxicity, larvae Culex pipiens

\section{INTRODUCTION}

Since ancient times the people of Indonesia know and use medicinal plants as one of the efforts to overcome health problems before formal health care with synthetic chemicals touched the community. Utilization of pare leaves as one of the plants that can be used as insecticide mosquito larvae larvae (larvasida) that can be obtained from natural materials.

Larvacide is an ingredient insecticides capable of inhibiting life cycle or killing the larvae stage in their natural habitat or at potential habitat. A mosquito larvaside that effective must have fast work persistent at various breeding places mosquitoes, either on clean water or on polluted water (Haeni, 2008).

Mosquitoes are among the species of insects that receive great attention in human health, because it has the potential as a vector in the transmission of a disease. Insect borne diseases are a common problem in Indonesia. Efforts to control a lot of vector is done 
spraying several types of insecticides. The use of chemicals that are less cautious can pose a danger to human health that is shortness of breath when the smell is stinging and allergic to the skin, causing environmental pollution problem, besides synthetic chemicals can cause resisaten in mosquito (Araujo, et al., 2006). In order to achieve optimal effort and minimize the impact on the environment, an appropriate method should be developed for different areas of the environment. Therefore it is necessary to find another alternative that is more simple and not detrimental to environmental health (Samsuhidayat and Hutapea, 1991).

\section{MATERIAL AND METHOD}

\section{Materials}

Pare leaf Extract (Momordica charantia L.), aquadest, etanol, $n$-heksana, etil asetat, $n$-butanol, tween 80, larva nyamuk Culex pipiens instar III

\section{Procedure}

Sample Preparation leaf of Momordica charantia L were collected at Kutai Kartanegara town, Indonesia. The leafs were. The leafs were cleaned and drined. The dried sample was pulverized until 60 mesh.

Extractionof Maseration The air-dried sample (250 gr) was extracted using Ethanol 96\% (1000 mL) until 48 hours and filtrated. The residue obtained after extraction was reextracted with Ethanol 96\% (1000 mL) or until the filtrat was transparent. The extract were drained and concentrated under reduce pressure using Rotary Evaporator $\left(40-50^{\circ} \mathrm{C}\right)$. The ethanol extract was allowed to dry and its contstant weight was recorded.

Fractionated extracts performed with liquid-solid fractionation method. In this fractionation will be made -heksana $n$ extract fraction, ethyl acetate and $n$-butanol.

\section{Preparation of bio-indicators (Culex pipiens mosquito larvae)}

Culex pipiens mosquito larvae selected by criteria such as size, shape, and color of the uniform. In the third instar spines and funnel chest began to clear respiratory blackish brown. The test larva used was instar larvae of instar mosquitoes III. 


\section{Design of Larvicides Bioactivity Test of Pare Leaf Extract}

Table 1. Treatment of variation concentration of pare leaf extract

\begin{tabular}{|l|l|l|l|l|l|}
\hline \multirow{2}{*}{ Replication } & \multicolumn{5}{|c|}{ Concentration variation Pare Leaf Extract (Momordica charantia L.) } \\
\cline { 2 - 6 } & \multicolumn{1}{|c|}{1} & \multicolumn{1}{c|}{3} & \multicolumn{1}{c|}{5} & \multicolumn{1}{c|}{5} \\
\hline 1 & $\mathrm{KEK}_{1} \mathrm{U}_{1}$ & $\mathrm{KEK}_{2} \mathrm{U}_{1}$ & $\mathrm{KEK}_{3} \mathrm{U}_{1}$ & $\mathrm{KEK}_{4} \mathrm{U}_{1}$ & $\mathrm{KEK}_{5} \mathrm{U}_{1}$ \\
\hline 2 & $\mathrm{KEK}_{1} \mathrm{U}_{2}$ & $\mathrm{KEK}_{2} \mathrm{U}_{2}$ & $\mathrm{KEK}_{3} \mathrm{U}_{2}$ & $\mathrm{KEK}_{4} \mathrm{U}_{2}$ & $\mathrm{KEK}_{5} \mathrm{U}_{2}$ \\
\hline 3 & $\mathrm{KEK}_{1} \mathrm{U}_{3}$ & $\mathrm{KEK}_{2} \mathrm{U}_{3}$ & $\mathrm{KEK}_{3} \mathrm{U}_{3}$ & $\mathrm{KEK}_{4} \mathrm{U}_{3}$ & $\mathrm{KEK}_{5} \mathrm{U}_{3}$ \\
\hline
\end{tabular}

Information

$\mathrm{KEK}_{1} \mathrm{U}_{1} \quad$ : Treatment of the first crude extract concentration on the first replay

$\mathrm{KH}_{1} \mathrm{U}_{1} \quad$ : Treatment concentration $\mathrm{n}$-hexane fraction first in first repeat

$\mathrm{KEA}_{1} \mathrm{U}_{1} \quad$ : Treatment concentration of ethyl acetate fraction first in first repeat

$\mathrm{KB}_{1} \mathrm{U}_{1} \quad$ : Treatment concentrations of $\mathrm{n}$-butanol fraction first in first repeat

\section{Larvicides bioactivity test of Pare Leaf Extract to Culex pipiens mosquito larvae}

Entered 10 Culex pipiens mosquito larvae was added to the vial containing water up to 10 $\mathrm{mL}$. In each vial was treated differently according to the prepared test group then covered with aluminum foil and given a small hole above it. Observed, noting the number of Culex pipiens mosquito larvae mortality after 24 hours. $\mathrm{LC}_{99}$ values are calculated crude extract ethanol, $n$-heksana fraction, of ethyl acetate and $n$-butanol fraction pare leaf (Momordica charantia L.) to Culex mosquito larvae mortality pipiens.

Analysis of Data The data was described with table and graph. The lethal dose of 99\% (LD99) was determined by Reed and Muench method.

\section{RESULTS AND DISCUSSION}

\section{Extract and Fractionation of Pare Leaf Extract}

Pare leaf extract (Momordica charantia L.) is a leaf pare that has beeb extracted by maceration by maceration method using ethanol andwith bulbs of $250 \mathrm{~g}$. The maceration process causes the solvent to penetrate the cell wall and into the cell cavity containing the active substance. The active substance will dissolve together with organic solvent in the presence of different concentrations between the active substance solution inside the cell and outside the cell, then the concentrated solution will be pushed out. The event will be repeated 
resulting in a concentration equilibrium between the solution outside and inside the cell. After conducting the subsequent sampling, the concentration of the sample solution which is aimed to obtain the concentrated extract. Concentration is done by using a rotary evaporator. This method aims to compounds Metab secondary olit not damaged by high temperatures. To avoid the use of temperature on the concentration used process vacuum pumps, resulting in reduced pressure and the solvent will evaporate at a temperature below its boiling point (Dervish, 2000).

Extracts were obtained from $250 \mathrm{~g}$ dry sample is $22: 16 \mathrm{~g}$, so that can know the amount of the yield obtained is at 8.86. To identify the components of a mixture based on the level of the polarity of a compound fractionation process is carried out. The purpose of this fractionation is to see bandage dingan pare leafextract bioactivity larvicides against the mosquito larvae Culex pipens. Rendemen analysis faction aims to know the percentage of fraction produced from the extract by fractionation method. Results yield extracts and fractions can be seen in Table 2 the following:

Table 2. The results yield leaf extract of pare leaf exract (Momordica charantia L.)

\begin{tabular}{|l|l|c|c|c|c|}
\hline No & \multicolumn{1}{|c|}{ Extract } & $\begin{array}{c}\text { Extract } \\
\text { Weight(g) }\end{array}$ & $\begin{array}{c}\text { Rendemen I } \\
(\mathbf{\%})\end{array}$ & $\begin{array}{c}\text { Rendemen II } \\
(\boldsymbol{\%})\end{array}$ & $\begin{array}{c}\text { Rendemen III } \\
(\boldsymbol{\%})\end{array}$ \\
\hline 1 & Ekstrak etanol & 22.16 & 2.67 & 8.86 & - \\
\hline 2 & Fraksi $n$-heksana & 2.50 & 0.30 & 1.00 & 13.16 \\
\hline 3 & Fraksi Etil asetat & 4.50 & 0.54 & 1.80 & 23.68 \\
\hline 4 & Fraksi $n$-butanol & 2.00 & 0.24 & 0.80 & 10.53 \\
\hline
\end{tabular}

\section{Larvicides bioactivity test of Pare Leaf Extract to Culex pipiens mosquito larvae}

To determine the bioactivity of larvicides leaf extract of pare leaf extract (Momordica charantia L.) then tested the mosquito larvae mortality with the use of acute toxicity tests. This test is designed to determine the toxic effect of a compound that will occur in a short time or administration with a certain dose (Department of Therapeutic Pharmacology, 2000). This test is a toxicology bioactivity test that aims to determine the biological activity of the extract or fraction of plants by observing the death response in experimental animals. The death of the experimental animal is considered as a response to the influence of certain compounds. This test is important to obtain information regarding the concentration relationship with death response of experimental animals (Colagate and Russel, 1993). 
Test the efficacy of the ethanol extract of pare leaf extract (Momordica charantia L.) against larvae of Aedes aegypti has been investigated by Lianawati (2008). The results of these studies conclude that the leaf extract of pare leaf extract (Momordica charantia L.) has the ability to kill mosquito larvae of Aedes aegypti with LC 50 value of 654.24 ppm and the LC 90 for 1588.40 ppm.. This study aimed at testing the rough ethanol extract, extract fraction of $n$-hexane, ethyl acetate fraction extract and extract of $n$-butanol fraction of the Culex pipiens mosquito larvae.

This study uses the mosquito Culex pipiens larva the third instar. First instar larvae are stable and resistant to changes in temperature and humidity (Hanti, 1996). The mosquito larvae in the third instar is more perfect than the physiological and morphological third instar larvae thus more resistant to the materials of larvicides. Therefore it can be concluded that the concentration that kills $100 \%$ of larvae of mosquitoes instar III also can kill mosquito larvae instar III and not vice versa.

Results of testing the bioactivity of larvicides ethanol crude extract obtained from the leaves of bitter melon five concentration variations with 3 repetitions. The test results are shown in Table 3 :

Table 3. The results of bioactivity test larvicides ka sar ethanol extract of the $l$ pare leaf extract (Momordica charantia L.) against Culex pipiens mosquito larvae

\begin{tabular}{|c|c|c|c|c|c|c|c|}
\hline \multirow{2}{*}{ Concentration } & \multirow{2}{*}{$\begin{array}{c}\text { Log } \\
\text { Concentration }\end{array}$} & \multicolumn{2}{|c|}{ Amount } & \multicolumn{2}{|c|}{ Accumulate } & \multirow{2}{*}{$\begin{array}{c}\text { Ratio to } \\
\text { tally dead } \\
\text { Accumulate } \\
x:(x+y)\end{array}$} & \multirow{2}{*}{$\begin{array}{c}\begin{array}{c}\text { Mortality } \\
(\%)\end{array} \\
\text { Ratio x } \\
100 \%\end{array}$} \\
\hline & & Die & Life & $\begin{array}{l}\text { Die } \\
(\mathbf{x})\end{array}$ & $\begin{array}{l}\text { Life } \\
(y)\end{array}$ & & \\
\hline $3750 \mathrm{ppm}$ & 3.57 & 9 & 21 & 9 & 45 & 0.1667 & 16.67 \\
\hline $5000 \mathrm{ppm}$ & 3.69 & 15 & 15 & 24 & 24 & 0.5000 & 50.00 \\
\hline $6250 \mathrm{ppm}$ & 3.79 & 21 & 9 & 45 & 9 & 0.8384 & 83.84 \\
\hline $7500 \mathrm{ppm}$ & 3.87 & 30 & 0 & 75 & 0 & 1 & 100 \\
\hline $8750 \mathrm{ppm}$ & 3.94 & 30 & 0 & 105 & 0 & 1 & 100 \\
\hline
\end{tabular}

In Table 3 above shows the test results crude extract ethanol, in which the lowest test concentration of $3750 \mathrm{ppm}$ has been giving activity in killing mosquito larvae Culex pipiens and the high concentration of $8750 \mathrm{ppm}$ level Culex pipiens mosquito larvae mortality give effect to kill all the test animals. This is in accordance 
with Harborne (1987) which states that the higher the concentration is given, the higher the death rate bioindikator.

The influence of the concentration of ethanol crude of pare leaf extract (Momordica charantia L.) the death of Culex pipiens mosquito larvae in shows that their effect on mortality of Culex pipiens concentration of crude extract ethanol. The results of test analysis using the method of Reed and Muench LC 99 values obtained ethanol crude extract of $7416.52 \mathrm{ppm}$. The increase of extract concentration is directly proportional to the number of test animals that died and vice versa inversely to the number of live test animals. Increasing concentrations of ethanol crude extract of leaves of bitter melon (Momordicacharantia L.) provides an increased ability to kill mosquito larvae Culex pipiens, this is because the more concentrated solution concentration, the more substances contained in the leaf extract of pare leaf extract (Momordica charantia L.), which means the more toxins consumed Culex pipiens mosquito larvae, so the number ofmosquito larvae mortality is also higher. This is in accordance with Nurhayati (2005) states the more concentrated solution concentration means more active ingredient which can interfere with the metabolism of the test animals.

\section{Larvicides bioactivity test of Pare Leaf fraction $\boldsymbol{n}$-hexane to Culex pipiens mosquito larvae}

Results bioactivity test of Pare Leaf fraction $n$-hexane to Culex pipiens mosquito larvae can be seen in Table 4 :

Table 4. Bioactivity test of Pare Leaf fraction $n$-hexane to Culex pipiens mosquito larvae

\begin{tabular}{|c|c|c|c|c|c|c|c|}
\hline \multirow{2}{*}{ Concentration } & \multirow{2}{*}{$\begin{array}{c}\text { Log } \\
\text { Concentration }\end{array}$} & \multicolumn{2}{|c|}{ Amount } & \multicolumn{2}{|c|}{ Accumulate } & \multirow{2}{*}{$\begin{array}{c}\text { Ratio } \\
\text { totally dead } \\
\text { Accumulate } \\
x:(x+y)\end{array}$} & \multirow{2}{*}{$\begin{array}{c}\text { Mortality } \\
\% \% \\
\text { Ratio x } \\
100 \%\end{array}$} \\
\hline & & Die & Life & $\begin{array}{l}\text { Die } \\
(\mathbf{x})\end{array}$ & $\begin{array}{l}\text { Life } \\
(y)\end{array}$ & & \\
\hline $750 \mathrm{ppm}$ & 2.87 & 18 & 12 & 18 & 29 & 0.2429 & 38.29 \\
\hline $1250 \mathrm{ppm}$ & 2.99 & 21 & 9 & 39 & 17 & 0.6964 & 69.64 \\
\hline $1750 \mathrm{ppm}$ & 3.24 & 25 & 5 & 64 & 8 & 0.8887 & 88.87 \\
\hline $2250 \mathrm{ppm}$ & 3.35 & 27 & 3 & 91 & 3 & 0.9681 & 96.81 \\
\hline $2750 \mathrm{ppm}$ & 3.44 & 30 & 0 & 121 & 0 & 1 & 100 \\
\hline
\end{tabular}


Effect of Pare Leaf fraction $n$-hexane the death of Culex pipiens in shows that increasing the concentration of n-hexane fraction is directly proportional to the number of test animals that die and instead is inversely proportional to the number of test animals were alive. Increasing concentrations of n-hexane fraction leaves of Pare Leaf fraction $n$-hexane improve the ability to kill mosquito larvae of Culexpipiens. Analysis using the method of Reed and Muench LC 99 values obtained $n$-heksana extract fraction of 2564.48 ppm.

\section{Larvicides Bioactivity test of Pare Leaf Fraction Ethyl Acetate to Culex pipiens mosquito}

\section{Larvae}

Results bioactivity test of Pare Leaf fraction ethyl acetate to Culex pipiens mosquito larvae can be seen in Table 5 :

Table 5. Bioactivity test of Pare Leaf fraction Ethyl Acetat to Culex pipiens mosquito larvae

\begin{tabular}{|l|l|l|l|l|l|l|l|}
\hline \multirow{2}{*}{ Concentration } & \multicolumn{2}{|c|}{$\begin{array}{c}\text { Log } \\
\text { Concentration }\end{array}$} & \multicolumn{2}{|c|}{$\begin{array}{c}\text { Amount } \\
\text { Accumulate }\end{array}$} & $\begin{array}{c}\text { Ratio } \\
\text { totally dead }\end{array}$ & $\begin{array}{c}\text { Mortality } \\
\text { \% }\end{array}$ \\
\cline { 3 - 9 } & & Die & Life & $\begin{array}{r}\text { Die } \\
(\mathbf{x})\end{array}$ & $\begin{array}{c}\text { Life } \\
(\mathbf{y})\end{array}$ & $\begin{array}{c}\text { Accumulate } \\
\mathbf{x}:(\mathbf{x}+\mathbf{y})\end{array}$ & $\begin{array}{c}\text { Ratio } \mathbf{x} \\
\mathbf{1 0 0 \%}\end{array}$ \\
\hline $750 \mathrm{ppm}$ & 2.87 & 6 & 24 & 6 & 72 & 0.0769 & 7.69 \\
\hline $1250 \mathrm{ppm}$ & 2.99 & 9 & 21 & 15 & 48 & 0.2380 & 23.80 \\
\hline $1750 \mathrm{ppm}$ & 3.24 & 15 & 15 & 30 & 27 & 0.5263 & 52.63 \\
\hline $2250 \mathrm{ppm}$ & 3.35 & 18 & 12 & 48 & 12 & 0800 & 80.00 \\
\hline $2750 \mathrm{ppm}$ & 3.44 & 30 & 0 & 78 & 0 & 1 & 100 \\
\hline
\end{tabular}

Effect of Pare Leaf fraction ethyl acetate the death of Culex pipiens in shows that increasing the concentration of ethyl acetate fraction is directly proportional to the number of test animals that die and instead is inversely proportional to the number of test animals were alive. Increasing concentrations of ethyl acetate fraction leaves of Pare Leaf fraction ethyl acetate improve the ability to kill mosquito larvae of Culex pipiens. Analysis using the method of Reed and Muench LC 99 values obtained ethyl acetate extract fraction of 2702.09 ppm.

\section{Larvicides bioactivity test of Pare Leaf fraction $\boldsymbol{n}$-butanol to Culex pipiens mosquito larvae}

Results bioactivity test of Pare Leaf fraction $n$-butanol to Culex pipiens mosquito larvae can be seen in Table 6 : 
Table 6. Bioactivity test of Pare Leaf fraction $n$-butanol to Culex pipiens mosquito larvae

\begin{tabular}{|l|l|l|l|l|l|l|l|}
\hline \multirow{2}{*}{ Concentration } & \multirow{2}{*}{$\begin{array}{c}\text { Log } \\
\text { Concentration }\end{array}$} & \multicolumn{2}{|c|}{ Amount } & \multicolumn{2}{c|}{ Accumulate } & $\begin{array}{c}\text { Ratio totally } \\
\text { dead }\end{array}$ & $\begin{array}{c}\text { Mortality } \\
\%\end{array}$ \\
\cline { 3 - 9 } & & Die & Life & $\begin{array}{r}\text { Die } \\
(\mathbf{x})\end{array}$ & $\begin{array}{c}\text { Life } \\
(\mathbf{y})\end{array}$ & $\begin{array}{c}\text { Accumulate } \\
\mathbf{x}:(\mathbf{x}+\mathbf{y})\end{array}$ & $\begin{array}{c}\text { Ratio x } \\
\mathbf{1 0 0 \%}\end{array}$ \\
\hline $750 \mathrm{ppm}$ & 2.87 & 9 & 21 & 9 & 60 & 0.0869 & 8.69 \\
\hline $1250 \mathrm{ppm}$ & 2.99 & 12 & 18 & 21 & 39 & 0.3500 & 35.00 \\
\hline $1750 \mathrm{ppm}$ & 3.24 & 15 & 15 & 36 & 21 & 0.6316 & 63.16 \\
\hline $2250 \mathrm{ppm}$ & 3.35 & 24 & 6 & 60 & 6 & 0.9091 & 90.91 \\
\hline $2750 \mathrm{ppm}$ & 3.44 & 30 & 0 & 90 & 0 & 1 & 100 \\
\hline
\end{tabular}

Effect of Pare Leaf fraction $n$-butanol the death of Culex pipiens in shows that increasing the concentration of n-butanol fraction is directly proportional to the number of test animals that die and instead is inversely proportional to the number of test animals were alive. Increasing concentrations of n-butanol fraction leaves of Pare Leaf fraction ethyl acetate improve the ability to kill mosquito larvae of Culex pipiens. Analysis using the method of Reed and Muench LC 99 values obtained ethyl acetate extract fraction of 2665.63 ppm.

Based on these descriptions, it is known that the crude extract of ethanol and the three extract fractions tested had as larvicidal activity, it is in accordance with Dalimartha (2008), which explains that bitter melon plants can be used to kill insects. Pare leaf extract and the fractions have the activity level is different, the difference in larvicidal activity of extracts and fractions caused some fractionation process wherein the compound contained in the extract chemical separation based on the degree of polarity so as to provide a different larvicidal activity.

The content of compounds in bitter melon leaves are flavonoids, alkaloids, saponins and terpenoids (Syamsuhidayat and Hutapea, 1991). Based on the study h acyl phytochemical test extracts or extract fractions pare leaf by Hernawati (2006) in his research on the potential p acre fruit (Momordica charantia L.) as a herbal ntifertilitas show that ethanol crude extract contains alkaloids, saponins, flavonoids, and triterpenes oid. Fraction $n$-hexane containing triterpenoids,flavonoids containing ethyl acetate and $n$-butanol containing flavonoids. 
Fortunately (1993) and Kristanti (2008) explains that the insecticide can get into the insect's body through various ways, among others: as a stomach poison(stomatch poison) that goes into the insect's body through the digestive tract of insects, gastrointestinal tract mosquitoes have a structure such as a wall body. Thus the absorption of insecticides in the digestion equals absorption of the body wall. Contact poison (contact Poisoining) that enter through the skin or body wall, dinding body part that can absorb large amounts of insecticide. The body wall has a base layer that are semipermeable membrane so that it can choose the types of compounds that can pass through and the last one fumigant or breathing into the insect's body through the respiratory system. The respiratory tract is called the trachea. Air and oxygen enter the trachea by diffusion assisted by abdominal movement. Oxygen will be directly related to the network. Insecticides enter the respiratory system in the form of gas or fine grains that are brought to the living tissue.

Function alkaloids, triterpenoids, saponins and flavonoids in the leaves of bitter melon can hinder eating larvae (antifedant). These compounds can enter the digestive through immersion extract concentration ingested by the larvae of the mosquito Culex pipiens, then enter the digestive tract and are absorbed by the intestinal wall and then circulate along the blood that would interfere with the metabolism of the body of the mosquito larvae Culex pipiens that lack of energy for activities that lead to Mosquitoes finally die. The workings of these compounds is to act as stomatch poisoning or stomach poison. Therefore, if these compounds are included in the larval body, ala t be disturbed digestion (Cahyadi, 2009).

\section{CONCLUSION}

The crude extract of bitter melon leaves ethanol and fractions have an activity as larvicides against the mosquito larvae Culex pipiens the $\mathrm{LC}_{99}$ value of each is at $7416.52 \mathrm{ppm}$ ethanol extract, extract $n$-heksana fraction $2564.48 \mathrm{ppm}$, extract ethyl acetate fraction $2702.09 \mathrm{ppm}$ and extract $n$-butanol fraction $2665.63 \mathrm{ppm}$.

\section{ACKNOWLEDGEMENTS}

The development of this plant needs to be done because this plant is easy to find and the number is many. E kstrak and pare leaf extract fraction having as larvicidal activity. Extract fraction $n$-heksana known to have the most excellent larvicidal activity, these results can be used as a reference in use are the most excellent naan extract as larvicides for further research so that the development of further research on bitter melon leaves that leads 
to the use of these crops is necessary, the isolation of pure compound From leaf pare is a way of development further to do in the future so that it can be used as a natural larvicidal derived from leaf extracts of bitter melon (Momordica charantia L.).

\section{REFERENCES}

[1] Andreanus A. Soemardji, E. Kumolosasi, S. Aisyah, 2002. Oral acute toxicity and LD50 of Gandarusa (Justicia gendarussa Burn. F) leaf extract on Swiss Webster Mice. Jurnal Matematika dan Sains. Institut Teknologi Bandung. Bandung.

[2] Haeni, I. N. 2008. Uji Laboratorium Pemberian Insect Growth Regulator Pyriproxyfen terhadap Pertumbuhan dan Perkembangan Larva Aedes aegypti dan Aedes albopictus Asal Bantul, Daerah Istimewa Yogyakarta. Tesis. Yogyakarta: Universitas Gajah Mada.

[3] Araujo MG, Costa IC, Dantas B, Maia S, dan Freitas SM. 2006. Effect of Stalk and Leaf Extracts From Euphorbiaceae Species On Aedes aegypti (Diptera, Culicidae) Larvae. Rev. Inst. Med. Trop. S.Paulo

[4] Bahatiyanusa Rudi. 2006. Pengaruh Ekstrak Biji Pare Terhadap Mortalitas Larva Aedes aegypti. [Skripsi]. Fakultas Kedokteran Universitas Sebelas Maret. Solo

[5] Cahyadi Robby. 2009. Uji Toksisitas Akut Ekstrak Etanol Buah Pare (Momordica charantia L.) Terhadap Larva Artemia salina Leach Dengan Metode Brine Shrimp Lethality Test (BSLT). [Skripsi]. Universitas Diponegoro. Semarang

[6] Colagate, S. M dan Russel, J.M. 1993. Bioactive Natural Products. CRC press. London

[7] Dalimartha Setiawan. 2008. Atlas Tumbuhan Obat Indonesia. Volume 5. Pustaka Bunda. Jakarta

[8] Darwis D. 2000. Teknik Dasar Laboratorium dalam Penelitian Senyawa Bahan Alam Hayati. FMIPA Universitas Andalas. Padang

[9] Departemen Farmakologi Terapeutik. 2000. Farmakologi dan Terapi. Edisi 5. Gaya Baru. Jakarta

[10] Departemen Kesehatan Republik Indonesia. 1986. Sediaan Galenik. DIRJEN POM. Jakarta

[11] Departemen Kesehatan Republik Indonesia. 2000. Sediaan Galenik dan Uji Klinik Obat Tradisional. DIRJEN POM. Jakarta

[12] Fanani R. 2009. Uji Toksisitas Akut Ekstrak Etanol Daun Dewanduru (Eugenia uniflora L.) Per Oral pada Tikus Galur Sprague Dawley. [Skripsi]. Universitas Muhammadiyah Surakarta. Surakarta

[13] Gandahusada S, Henry, Pribadi W. 1998. Parasitologi Kedokteran Edisi Ketiga. Balai Penerbit FKUI. Jakarta 
[14] Harborne, J.B. 1987. Metode Fitokimia. Penuntun Cara Modern Menganalisa Tumbuhan. Penerbit ITB. Bandung

[15] Hendayana. 2006. Kimia Pemisahan. Rosda. Bandung

[16] Hernawati. 2008. Potensi Buah Pare (Momordica charantia L.) Sebagai Herbal Antifertilitas. [Laporan Akhir Penelitian]. Jurusan Biologi Fakultas Matematika dan Ilmu Pengetahuan Alam Universitas Pendidikan Indonesia. Bandung

[17] Kristanti dan Alfinda Novi. 2008. Fitokimia. Airlangga University Press. Surabaya

[18] Lestari, Bekti D, Gama Z, Rahardi Brian. 2009. Identifikasi Nyamuk Di Kelurahan Sawojajar Kota Malang. Fakultas Kesehatan Masyarakat Universitas Muhammadiyah Malang. Malang

[19] Levine, N.D. 1995. Buku Pelajaran Parasitologi Veteriner. Gadjah Mada University Press. Yogyakarta

[20] Lianawati Hefi. 2008. Uji Efikasi Daun Pare (Momordica charantia L.) Terhadap Larva Nyamuk Aedes aegypti [Skripsi]. Fakultas Kesehatan Masyarakat Universitas Diponegoro. Semarang

[21] Nunung Nurhayat. 2005. Pengaruh Jenis Pelarut dan Konsentrasi Ekstrak Umbi Gadung (Dioscorea hispida Dennst) Terhadap Mortalitas Larva Aedes aegypti L. [Skripsi]. Fakultas Kesehatan Masyarakat Universitas Muhammadiyah Malang. Malang

[22] Nurmaini. 2001. Identifikasi Vektor dan Binatang Pengganggu serta Pengendalian Anopheles Aconitus secara Sederhana [Skripsi]. Fakultas Kesehatan Masyarakat Universitas Sumatera Utara. Sumatera Utara

[23] Nurmaini. 2003. Mentifikasi Vektor dan Pengendalian Nyamuk Anopheles. Aconitus Secara sederhana [Skripsi]. Fakultas Kesehatan Masyarakat Universitas Sumatera Utara. Sumatera Utara

[24] Nursakinah. 2008. Efficacy Bioinsectiside Extract Mulwo Leaf (Annona feticula L.) As Larvacide to Aedes Aegepty In Laboratory [Skripsi]. Fakultas Kesehatan Masyarakat Universitas Muhammadiyah Semarang. Semarang

[25] Rosa Emantis, Setyaningrum E, Murwani S, Halim. 2009. Identifikasi dan Aktivitas Menggigit Nyamuk Vektor Malaria Di Daerah Pantai Puri Gading Kelurahan Sukamaju Kecamatan Teluk Betung Barat Bandar Lampung [Skripsi]. FMIPA Universitas Lampung. Lampung

[26] Sastrohamidjojo H. 1995. Sintesis Bahan Alam. Liberty. Yogyakarta

[27] Setyawati Hening. 2008. Aktivitas Antimikroba Fraksi dari Ekstrak n-heksana Buah Pandanus conoideus Lamk Terhadap Staphylococcus aureus ATTC 25923, Escherichia coli ATCC 25922, dan Candida albicans [Tesis]. Fakultas Farmasi Universitas Airlangga. Surabaya 
[28] Soegijanto Soegeng. 2004. Demam Berdarah Dengue. Airlangga University Press. Jakarta

[29] Syamsuhidayat, S. dan Hutapea, J.R. 1991. Inventaris Tanaman Obat Indonesia. Depkes RI. Jakarta

[30] Untung K. 1993. Kemungkinan Ketahan Aedes aegypti Terhadap Pestisida di Indonesia. (Online), (http://kasumbogo.staff.ugm.ac.id/detailmessge.php)

[31] Voigt Rudolf. 1984. Teknologi Farmasi. Diterjemahkan oleh Soendari Noerono Soewandhi. Gajah Mada University Press. Yogyakarta

[32] Wahyuningsih Hanti. 1996. Uji Kepekaan Larva Nyamuk Anopheles aconitus Terhadap Ekstrak Daun Bengkuang (Pachyrrhizus erosus). [Skripsi]. Fakultas Kesehatan Masyarakat Universitas Diponegoro. Semarang

[33] Waren, K.S 1993. Immunology and Molecular Biology of Parasitic Infection $3^{\text {rd }}$. Blackwell Scientific Publication. Boston

[34] Widiarti. 1991. Tinjauan Penelitian Pengendalian Vektor Malaria Secara Hayati dan Pengelolaan Lingkungan. Pusat Penelitian Ekologi Badan LitBangKes DepKes RI. Jakarta 